\title{
Shaking the Foundations of Biopolitics
}

\author{
Anna E Kubiak* \\ Institute of Philosophy and Sociology, Polish Academy of Sciences, Poland, Europe
}

Submission: January 27, 2018; Published: April 04, 2018

*Corresponding author: Anna E Kubiak, Institute of Philosophy and Sociology, Polish Academy of Sciences, Poland, Europe, Email: akubiak@ifispan.waw.pl

Abstract

The objective of this opinion is to draw the outline of the condition of late modern biopolitics. The notion of "biopolitics is understood after Michele Foucault, Paul Rabinow and Nikolas Rose. The main observation is that the foundations of biopower are shaking because of resistance movements. Resistance toward biopower is specifically visible in end-of-life issues.

Keywords: Biopolitics; End of life; Resistance

\section{Introduction}

After analyzing different areas of biopolitics (medicine, bioethics, law, policy, health-care system and economy in Poland, Europe and USA), I observe tiny "folds" and "cracks" in the foundations of biopower. The term "biopolitics"/ "biopower" is focused on the population and means strategies, clarification of knowledge, control and all practices in the name of life [1]. It is the efficient system of a society of control where life becomes a political object. Resistance toward biopower is specifically visible in end-of-life issues. I argue that biopolitics has been in crisis since the 1990s [2]. Since then, the period of doubt in selfknowledge of bioethicists and doctors about the border between life and death has begun. The outcome of this quiet revolution is unknown, but is expressed in blurring the borders of the crucial categories, first of all, between life and death, but also between human beings and animals, and human beings and cyborgs, and anomalies questioning paradigms of the regimes of truth. I do not suggest that the emancipation movement for "letting die" will be necessary followed by the radical transgression of biopower. I only observe that there are growing margins, "grey zones," beside biopower typologies, embodied in patient's groups fighting for their rights, individuals claiming the right to their death and organizations of the kind of Compassion \& Choices (previously, Hemlock Society), working for the legalisation of euthanasia and assisted suicide in the USA, while also helping people to commit suicide. These movements, consisting also of diaries and blogs of dying people, all reveal the chaos and horror of dying (while not necessary asking for the right to die) and those that have "letting die" as their telos.

The area of uncertainty and unpredictability is driving biopolitics into a crisis. I use the notion of "uncertainty" to express the impression of being hit by anxiety, public distrust in biotechnological revolution and the growing consciousness that fewer and fewer things depend on individual projects, and this anxiety and distrust acts in opposition to the ideology of neoliberalism. Terrorism and ecological catastrophes create situations where social control is weak and the only possible action is to try to lessen the negative consequences: to mobilize additional military and police forces or to build dams against a flood. I see the split between modernity with its immunological systems and our crisis time when we still built security systems but we don't believe in their perfect protection, e.g. in the case of terrorism, cyber-spying, GMO or medical vaccine. The category of "uncertainty," which I use in describing medical, legislative and economic issues, may be the only argument for the fact that biopower instruments face resistance.

It is difficult to prognosticate a radical change in reaction to the main symptoms of our unstable time, but if so, it will be not a revolution or an explosion, but rather an "implosion." By this notion, Jean Baudrillard describes a threat to accumulation, power and consumer society that can be "dismantled, but (implosion - AEK) does not stem from revolutionary resistance from outside, but from a kind of dissolution from inside" [3]. He defines "implosion" as: "The absorption of one pole into another, the short circuiting between poles of every differential system of meaning, the erasure of distinct terms and oppositions, including that of the medium and of the real - thus the impossibility of any mediation, of any dialectical intervention between the two or from one to the other" [4]. Michele Foucault notes that everywhere where the power works, there is "the strategic field of power relations" [5] of resistance and it always operates inside a network of power. Because grunts started to exhibit their friable consistency, so the cracks appeared on the foundations of institutions, social practices and discourses, which are being problematised. 
Biopolitics has been forced to constantly change the definition of death (putrefaction - cessation of the circulation of blood brain-death - neocortical death) as described by Margaret Lock [6]. The brain death definition is not accepted with applause by all scientists. Keeping bodies useful for transplantation creates new entities - although it sounds paradoxical - that are dead, but also alive. New creatures are ambiguous and remain in-between. Their status is best described as a suspension between life and death. These "living cadavers," neomortos, or hybrids, whose boundaries are blurred, include: brain-dead people, patients in a persistent vegetative state; "locked in" patients; those with minimal consciousness; and the severely demented. There are consequently conflicting diagnoses. Lock says that "Among the thirty-two intensivists (specialists who work in ICUs) whom I interviewed between 1995 and 1997, not one believes that brain death signals the end of biological life [...] As one intensivist put it, 'It is not death, but it is an irreversible diagnosis, which I accept"' [7]. Transplantation challenged medical practice, as maintaining organs mean "treating dead patients in many respects as if they were alive" [8]. There are continuous debates on when death occurs. "On some proposed definitions of death, those that involve higher brain formulations, an organism could be declared a corpse (meaning 'dead body' - AEK) while still breathing. Of the higher brain formulations, Lamb says: 'The notion of a still-breathing corpse is morally repugnant. How, for example, does one dispose of such being? Should burial or cremation take place while respiration continues? Or should someone take responsibility for suffocating the corpse first?' There are several points made in this quotation. The point of indeterminacy carries more weight than that concerning moral repugnance" [9]. Advancement of medical technology dramatically changed the condition of patients. Lock notes: "Among the many medical technologies in routine use, the artificial ventilator, a device that enables patients to breathe when they can no longer do so independently, means that we are often dealing today with entities suspended between life and death, the likes of which have never before been encountered. Living cadavers, as they were formerly known - now more commonly the 'brain dead' - have bodies that function close to 'normal', thanks to technological support, but their brains are permanently destroyed. Such patients become cyborgs, breathing with technological assistance but forever unconscious" [10]. As Hallam, Hockey and Howarth write: "As a result the dominant conceptual differentiation represented by the binary life/death becomes difficult to achieve in practice. Its (stillbirth, neonatal death and persistent vegetative state - AEK) status is reduced to little more than a hypothesis about the nature of human existence, rather than an incontrovertible reality. In practice, the life/death differentiation may be unstainable with any easy or clarity" [11]. Ambivalence of the status of hybrids causes hesitations of the diagnosis and of the agreement of a family of a patient for transplantation. The introduction of a new definition of death as "brain death" raised difficult, ambivalent situations. In this case, the theory has not completely been translated into practice. There is a disparity between life and death; there exists a "zone of indistinction," which involves doctors and lawyers in logical contradictions. New forms of existence, or as Willard Gaylin [12] calls them, neomortos, are individuals in a vegetative state, occupying an indefinite zone between life and death. According to the new definition, such a dead person remains fertile and is even able to give birth to a child as in the case of a woman, described by Peter Singer [13]. But it has been followed by ethical, medical and economical dilemmas. New questions arise, such as those asked by Singer, when he states: "Assuming that one is dead when the brain is dead, when does one die if the brain was not possessed in fact?" [14]. In the case of decisions regarding individuals in a persistent vegetative state, the issue of quality of life is raised. Thus, the old rule of the sanctity of life is replaced by a distinction between lives worth and not worth living. Medicine improved many technological interventions in the human body. As intensive care units are the most expensive wards of any hospital and they may involve discomfort and pain for a patient, there are in practice many hesitations and doubts about which patients should be treated in this way. The biggest challenges come from 21st-century life sciences. Defining "ranges of normal functioning within populations in order to know and be able to intervene in those groups" [15] is fundamental for biopower strategies. Biotechnology (tissue engineering, cloning) changes the social imagination of what is normal. Possibilities to create post-human beings, cyborgs, raise troublesome questions that are ontological, ethical, economic and political. These new possibilities from one side ignite old hopes about immortality, but from the other side, they give rise to uncertainty and even anxiety, best displayed in science fiction movies and films about zombie and vampires. New entities bring doubts about borders between nature and culture which are being blurred. New forms of existence that have emerged in late modernity due to medical technopol are forced to live according to telos of modernity. However, their status can be better grasped by the notion of the "living dead" [16] or "zombie."

\section{Conclusion}

Growing margins of uncertainty are followed by "cracks" in the foundations of biopower. On the other hand, I observe that this is the reason why biopolitics is undergoing a mobilization in the form of proliferation of norms (e.g. legislative, medical), more and more instruments applied: medical and bioethical commissions [15], legislative interventions, church's declarations, social "pro-life" movements, the discourses of the "promisive potential" [16] (e.g. of life sciences, pharmaceutical industry, shareholder value ideologies and travel agencies), and all projects for "making life". Junction points engage biopower in producing regulatory and repair mechanisms. I observe that there are symptoms of an implosion. 


\section{References}

1. Paul R, Nikolas R (2006) Biopower Today. BioSciences 1: 195-217.

2. Peter S (1997) $O$ życiu $i$ śmierci. Upadek etyki tradycyjnej (Rethinking Life and Death: The Collapse of Our Traditional Ethics) PIW, Warszawa p. 48

3. Ignaas D, Ine van $\mathrm{H}$ (2011) A New Era of Medical Consumption: Medicalisation Revisited, APORIA 3(3): 16-21.

4. Jean B (2001) Simulacra and simulation Ann Arbor, University of Michigan Press p. 83.

5. Michel F (2010) Historia seksualności (History of Sexuality) słowo/ obraz terytoria, Gdańsk p. 69.

6. Margaret L (2003) On Making Up the Good-as-Dead in a Utilitarian World. In: Franklin S, Lock M (Eds.), Remaking Life \& Death. Toward an Anthropology of the Biosciences. School of American Research Press, Santa Fe pp.165-192.

7. Stuart Y, Martha A, Edward B (1985) Psychological and Ethical Implications of Organ Retrieval, New England Journal of Medicine, 313: 321-324.

8. Chadwick Ruth F (1996) Corpses, recycling and therapeutic purposes. In: Lee R, Morgan D (Eds.), Death Rites Routledge, London p. 54-71.
9. Lock Margaret (2003) On Making Up the Good-as-Dead in a Utilitarian World. In: Franklin S, Lock M (Eds.), Remaking Life \& Death. Toward an Anthropology of the Biosciences School of American Research Press, Santa Fe, pp. 165-192.

10. Elisabeth H, Jenny H, Glennys H (1999) Beyond the Body London, Routledge, New York, USA p. 72.

11. Willard G (1974) “Harvesting the Dead”, Harpers 23(9): 74: 30.

12. Peter S (1997) O życiu i śmierci. Upadek etyki tradycyjnej (Rethinking Life and Death: The Collapse of Our Traditional Ethics) PIW, Warszawa p. 17-20.

13. Linda HF (2003) Life/Time Warranty: Rechargeable Cells and Extendable Lives. In: Franklin S, Lock M (Eds.), Remaking Life and Death. Toward an Anthropology of the Biosciences. School of American Research Advanced Seminar Series, Santa Fe: 61-96.

14. Achille M (2003) Necropolitics. Public Culture 1(15): 11-40.

15. Michael SJ (2007) The case against perfection. Ethics in the age of genetic engineering Belknap Press, Cambridge, Massachusetts.

16. Sarah F (2003) Ethical Biocapital: New Strategies of Cell Culture In: Franklin S, Lock M (Eds.), Remaking Life and Death. Toward an anthropology of the Biosciences School of American Research Advanced Seminar Series, Santa Fe: 97-128.

\section{Your next submission with Juniper Publishers will reach you the below assets}

- Quality Editorial service

- Swift Peer Review

- Reprints availability

- E-prints Service

- Manuscript Podcast for convenient understanding

- Global attainment for your research

- Manuscript accessibility in different formats

( Pdf, E-pub, Full Text, Audio)

- Unceasing customer service

Track the below URL for one-step submission https://juniperpublishers.com/online-submission.php 